\title{
Changes in the Content of Gibberellin-like Substances in the Seed of Prunus persica
}

\author{
by Yukiyoshi OGawA*
}

Received August 19, 1965

Parthenocarpy can be induced in Prunus by application of gibberellin ${ }^{1-2)}$. Early study showed that the extract of immature seed of Prunus had high activity of gibberellin-like substances ${ }^{3-4)}$. It would appear that the growth of Prunus fruit might be influenced by the content of seed gibberellins.

\section{Materials and Methods}

Fruits of Prunus persica, "Hakutō" were harvested on May 1st, 1962 (about 20 days after flowering). Thereafter, five fruits were picked every 15 days. The diameter and fresh weight of the fruits and seeds were recorded. The seeds were ground in a mortar, extracted three times with $25-\mathrm{m} l$ portions of 80 per cent ethanol, and filtered. The combined filtrate was dried and dissolved in a small volume of ethanol prior to ascending chromatography. Chromatography was carried out at about $25^{\circ}$ using Tōyō No. 51 filter paper strips and a mixture of iso-propanol, $7 \mathrm{~N}$ ammonium hydroxide and water $(8: 1: 1 \mathrm{v} / \mathrm{v} / \mathrm{v})$. The dried chromatographic strips were cut into 15 pieces. Each piece was then eluted with $1.5 \mathrm{~m} l$ of distilled water. The amount of gibberellin-like substances was determined by the rice seedling test ${ }^{5}$. In some cases, further information was acquired by using the Pharbitis ${ }^{4)}$ and dwarf maize tests $^{3)}$.

\section{Results and Discussion}

Growth of the fruit and seed

Growth rates of the seed and the fruit are shown in Fig. 1. Diameter of the fruit increased rapidly until about 50 days after flowering, thereafter very slowly. The fresh weight of the fruit increased rapidly reaching a maximum after about 80 days. The seed weight began to increase 35 days after flowering and its increase continued through the 95 days of observation.

Gibberellin-like substances in the seed

The activity of each strip of the chromatogram obtained from the extract from 3 seeds harvested about 50 days after flowering is represented in Fig. 2. The growth promoting activity was located at Rf $0.46-0.53$. There was growth inhibiting activity at $\mathrm{Rf} 0.66-0.86$. The amounts of gibberellin-like substances and the activities of the growth inhibitors contained in the seeds at different stages are shown in Fig. 3 . In the figure, the former are represented by gibberellin $\mathrm{A}_{3}$ equivalent values, and the latter by the decrease in length of the 2nd leaf sheath (as percentages of the controls). The amount of gibberellin-like substances began to increase 35 days after flowering and reached to a maximum on the 50th day, June 1st. The maximum value was about 18 times as high as that of the first sample. Thereafter it decreased rapidly. The changes in activity of the growth inhibitors are similar to those of the

* Laboratory of Applied Botany, Faculty of Agriculture, Kyoto University, Kyoto, Japan. 
gibberellin-like substances. As shown in Figs. 1 and 3 , the amounts of the gibberellin-like substances and the growth inhibitors in the seed increased with growth of the fruits and seeds, and attained their maximum when the fruit diameter

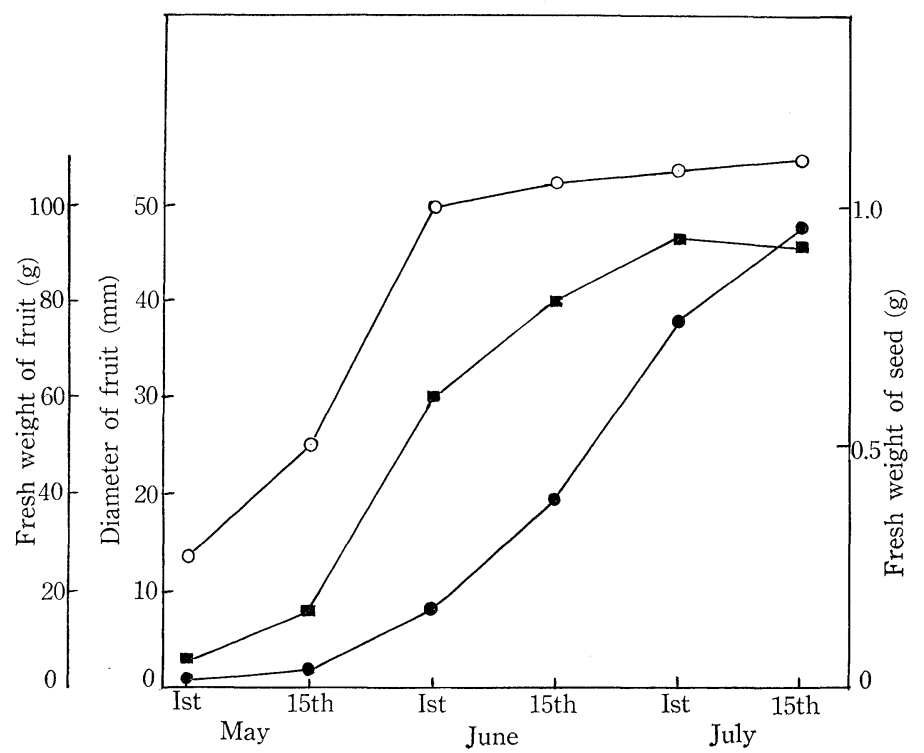

Fig. 1. Growth of seed and fruit of Prunus persica after anthesis.

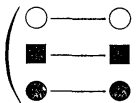

Diameter of fruit

Fresh weight of fruit

Fresh weight of seed

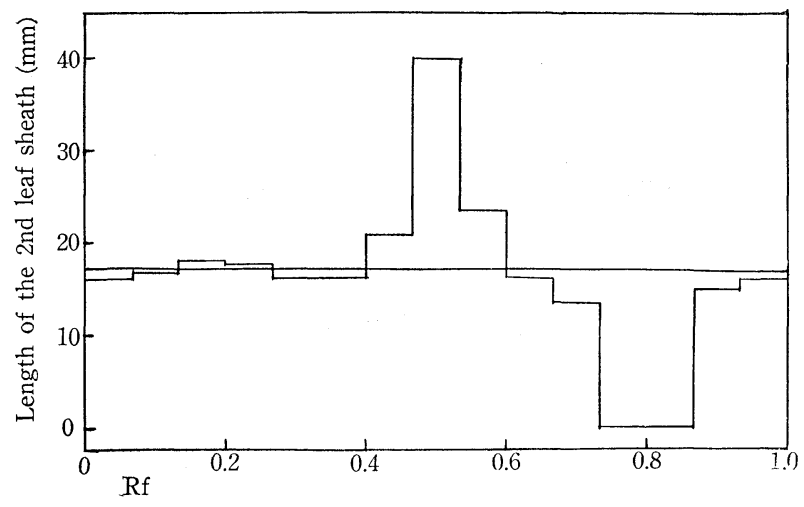

Fig. 2. Paper-chromatogram of $80 \%$ ethanol extract of Prunus seed harvested on June 1st.

reached its maximum, although the fruit and seed weights still continued to increase. When the fruit weight reached its maximum on July 1st, the amount of gibberellinlike substances in the seed had fallen to 20 per cent of its maximum level. 


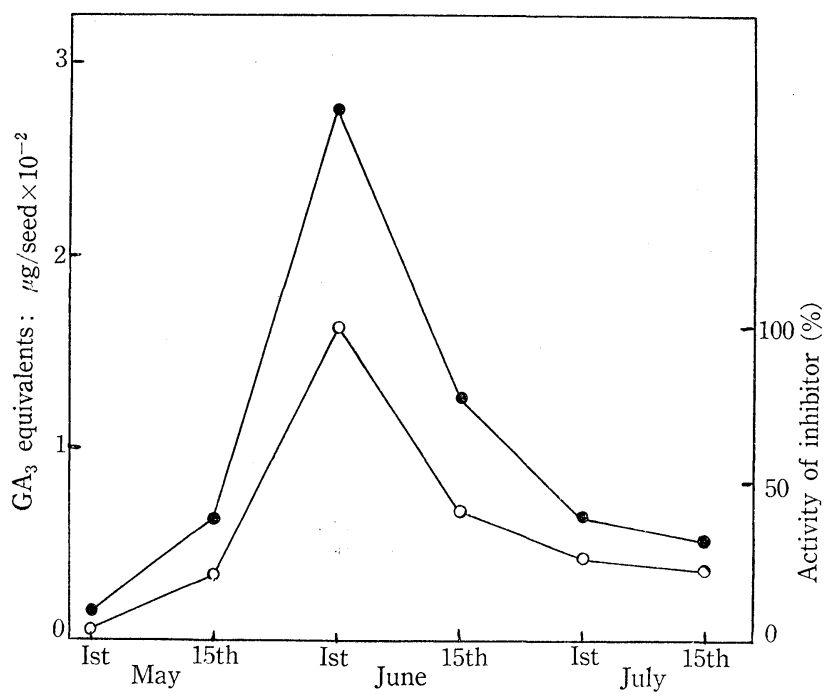

Fig. 3. Changes in amount of gibberellin-like substances and growth inhibitors in the Prunus seed after anthesis.

$$
\left(\begin{array}{ll}
- & \text { Gibberellin-like substances } \\
\bigcirc- & \text { Growth inhibitors }
\end{array}\right)
$$

Response of dwarf Pharbitis and dwarfs 1, 3 and 5 of maize to the extract

Ethanol extract from $5 \mathrm{~g}$ of fresh immature seeds was carried to dryness and taken up in water. The solution was adjusted to $\mathrm{pH} 3.0$ with $1 \mathrm{~N} \mathrm{HCl}$, and extracted with ethyl acetate for $12 \mathrm{hrs}$. using a percolator. The ethyl acetate and aqueous layers were separated. The ethyl acetate fraction was dried, and then dissolved in a small volume of ethanol for paper chromatography. The aqueous fraction was neutralized with 5 per cent sodium bicarbonate and also dried. This fraction was extracted three times with 95 per cent ethanol and the combined extracts were concentrated. Both fractions were submitted to paper chromatography. Aqueous eluates of segments of the dried chromatograms were assayed for activity in the rice seedling test. The ethyl acetate fraction showed a growth promoting activity in the Rf $0.40-0.60$ area and a growth inhibiting activity at $\mathrm{Rf} 0.53-0.87$. These Rf ranges were identical with those observed in the ethanol extract before the fractionation with ethyl acetate. No activities of the gibberellin-like substances and growth inhibitors were detected in the aqueous fraction.

The chromatogram strip obtained with the acidic ethyl acetate fraction ( $5 \mathrm{~g}$ seeds) was cut into 15 pieces and each was eluted with 80 per cent ethanol. The eluates were dried, taken up in $1 \mathrm{~m} l$ water, and assayed using dwarf Pharbitis and maize dwarfs 1,3 and 5 (Fig. 4).

Dwarf Pharbitis and the three dwarf mutants of maize responded to the gibberellin-like substances just as did the rice seedlings. Their response to the growth inhibitors was not observed.

Reports have been published regarding the content of gibberellin-like substances in the seed and fruit of several species of plants ${ }^{6-8}$. Ogawa showed that the amount of gibberellin-like substances in the seed of Lupinus luteus was at a high level during the first lag phase of fruit development ${ }^{6}$. 
The present experiments showed that the amount of gibberellin-like substances in Prunus persica seed increased with the fruit growth, and attained its maximum (as high as $0.03 \mu \mathrm{g}$ gibberellin $\mathrm{A}_{3}$ equivalents per seed) about 50 days after flowering. At this time the size of the fruit approached its maximum and the seed was enlarging. Bradley and Crane found that applied gibberellin promoted normal cell division and cell enlargement in the mesocarp of parthenocarpic peaches ${ }^{9}$. The evidences presented in the present paper suggest that gibberellin or gibberellin-like substances are the major growth factors produced in the seed of pollinated fruit.

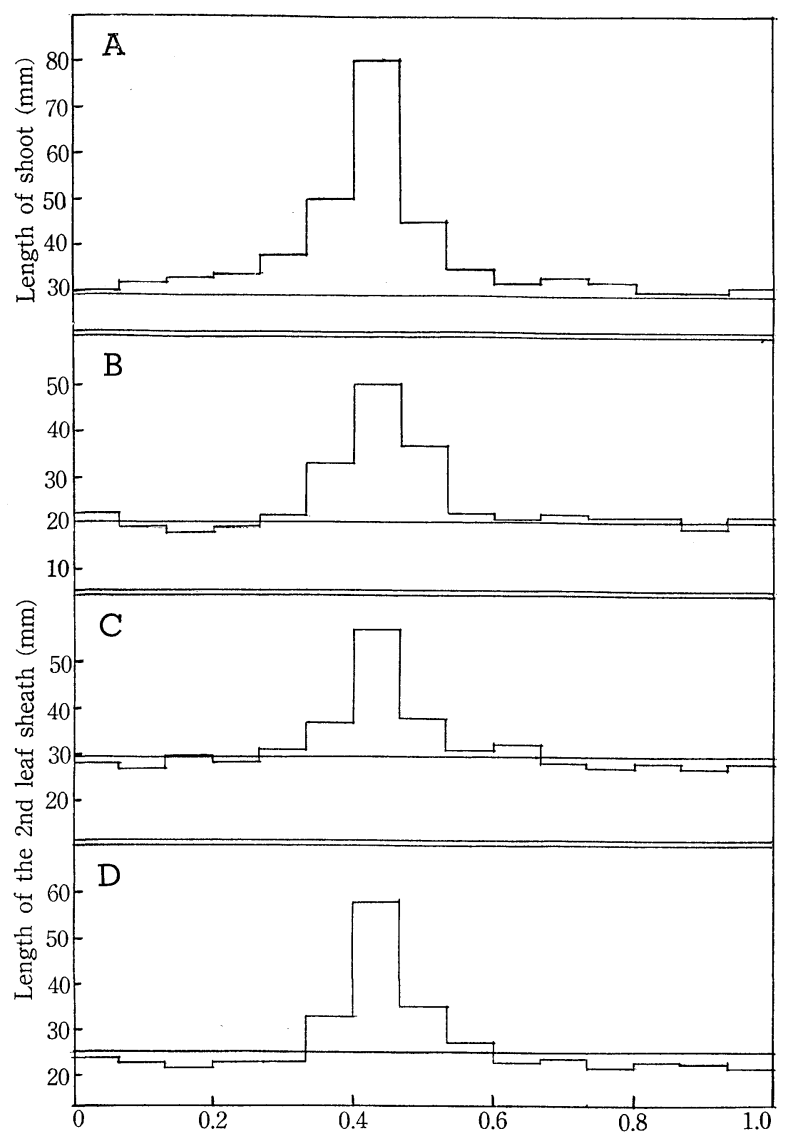

Fig. 4. Responses of dwarf Pharbitis (A) and dwarfs of maize $\mathrm{d}_{1}(\mathrm{~B})$, $\mathrm{d}_{3}(\mathrm{C})$ and $\mathrm{d}_{5}(\mathrm{D})$ to acid ethyl acetate fraction from Prunus seed.

These growth factors appear to be essential for fruit set, growth and development in Prunus.

The author is greatly indebted to Prof. S. Imamura for his suggestion and criticism in the course of this work, as well as to Dr. B. O. Phinney, University of California, for supplying us with seeds of maize mutants. His thanks are also due to Dr. W. R. Briggs, Stanford University, who kindly corrected the English of the manuscript. 


\section{Summary}

1. The change in amount of gibberellin-like substances in the seed of Prunus in persica in relation to the growth of the fruit was investigated by using the rice seedling test.

2. On chromatograms developed with ammoniacal iso-propanol, gibberellin-like activity was found at $\mathrm{Rf} 0.46-0.53$, while growth inhibiting activity was at $\operatorname{Rf} 0.66-0.86$.

3. The increase in amount of gibberellin-like substances in the seed corresponded with the fruit growth. The substances attained a maximum amount of $0.03 \mu \mathrm{g}$ gibberellin $A_{3}$ equivalents per seed about 50 days after flowering.

4. The gibberellin-like substances were also active on dwarf Pharbitis and dwarf maizes $d_{1}, d_{3}$ and $d_{5}$.

\section{References}

1) Crane, J. C., Primer, P. E., and Campbell, R. C., Proc. Amer. Soc. Hort. Sci. 75: 125 (1960). 2) Crane, J.C., ibid. 83: 240 (1963). 3) Phinney, B. O., West, C. A., Ritzel, M., and Neely, P. M., Proc. Natl. Acad Sci. 43: 298 (1957). 4) Hirono, Y., Ogawa, Y., and Imamura, S., Plant and Cell Physiol. 1: 81 (1960). 5) Ogawa, Y., ibid. 4: 125 (1963). 6) Ogawa, Y., ibid. 4: 85 (1963). 7) Corcoran, M. R., and Phinney, B. O., Physiol. Plantarum 15: 252 (1962). 8) Ogawa, Y., Plant and Cell Physiol. 4: 217 (1963). 9) Bradley, M. V., and Crane, J. C., Bot. Gaz. 123: 243 (1962).

摘 要

小川幸持：モモの種子に沶けるジベレリン様物質の含量の変化について

1. モモの種子に存在するジベレリン様物質と果実の生長の関係について調べた.

2. このジベレリン様物質はアンモニア性イソプロパノール展開ペーパークロマトグラム上で $\mathrm{Rf} 0.46-$ 0.53 の值を示した。生長抑制物質は Rf 0.66-0.86 の部分にみられた.

3. ジベレリン様物質の含量は果実の生長と平行して増加し, 開花後約 50 日で種子当り $0.03 \mu \mathrm{g}$ を示 した.

4. このジベレリン様物質はイネ芽生光，矮性アサガオ拈よび矮性トウモロコシ $\mathrm{d}_{1}, \mathrm{~d}_{3}, \mathrm{~d}_{5}$ の伸長を促 進する. (京都大学農学部応用植物学研究室) 